DOI: $10.19195 / 0137-1134.106 .28$

\title{
KRAJOWY SYSTEM RATOWNICZO-GAŚNICZY W SYSTEMIE BEZPIECZEŃSTWA WEWNĘTRZNEGO PAŃSTWA
}

\section{WSTĘP}

Przemiany społeczno-polityczne zapoczątkowane na przełomie lat 80. i 90. ubiegłego wieku spowodowały konieczność dokonania analogicznych zmian w systemie bezpieczeństwa wewnętrznego państwa. Powstały nowe formacje państwowe jako jednostki organizacyjne wykonujące zadania na potrzeby obrony oraz zapewnienia porządku publicznego, jak: Policja Państwowa ${ }^{1}$, Straż Granicz$n^{2}$; Państwowa Straż Pożarna ${ }^{3}$. Wymienione formacje wykonują również swoje ustawowe zadania w czasie kryzysu i stanów nadzwyczajnych (np. stan klęski żywiołowej, stan wyjątkowy, stan wojny). W poprzednim ustroju zadania z zakresu szeroko rozumianego bezpieczeństwa (na zasadach powszechności) wykonywały jednostki obrony cywilnej oraz inne państwowe jednostki organizacyjne, w tym przedsiębiorstwa państwowe.

W okresie funkcjonowania Układu Warszawskiego obrona cywilna ukierunkowana była na zapewnienie funkcjonowania wojska i jego potrzeb, w zasadzie nie uwzględniając głównych zadań, którym powinna służyć — bezpieczeństwu i możliwości przetrwania społeczeństwa. Jej organizację określała ustawa o powszechnym obowiązku obrony, co jednoznacznie nadawało jej charakter militarny. Zmiany zaczęły następować dopiero po 1991 r., po ratyfikacji przez RP

\footnotetext{
${ }^{1}$ Ustawa z dnia 6 kwietnia 1990 r. o Policji, tekst jedn. Dz.U. z 2015 r., poz. 355 ze zm.

2 Ustawa z dnia 12 października 1990 r. o Straży Granicznej, tekst jedn. Dz.U. z 2014 r., poz. 2014 ze zm.

${ }^{3}$ Ustawa z dnia 24 sierpnia 1991 r. o Państwowej Straży Pożarnej, tekst jedn. Dz.U. z 2013 r., poz. $1340 \mathrm{ze}$ zm.
} 
protokołu dodatkowego do konwencji genewskiej ${ }^{4}$. Sytuacja ta była raczej tylko sygnałem nadejścia czasu przemian w tym zakresie, ponieważ i tak do $1996 \mathrm{r}$. obrona cywilna realizowała zadania tak, jakby dalej trwał Układ Warszawski. Zasadniczą transformację OC rozpoczęto w roku 1997, przekształcając jej charakter militarny w charakter zadaniowy między innymi poprzez „ucywilnienie” wszystkich jej struktur, przenosząc odpowiedzialność za jej funkcjonowanie od Ministra Obrony Narodowej do Ministra Spraw Wewnętrznych. Problemem zostało obowiązujące prawo, które w swojej archaicznej postaci jest niestosowane, a obrona cywilna realizowana przez struktury cywilne państwa praktycznie otrzymała już charakter zadaniowy, niezależnie od obowiązujących dotychczas przepisów prawa. Uwzględniając powyższe, obrona cywilna nie jest systemem, lecz zadaniami do wykonania w czasie pokoju. Przykładem realizacji zadań z tego zakresu jest fakt przekazania z dniem 1 stycznia 1992 r. przez ówczesnego wojewodę wrocławskiego gminom majątku budżetu państwa będącego w posiadaniu „terenowych” ochotniczych straży pożarnych wchodzących w skład zgrupowania jednostek ratowniczych OC. Funkcjonowanie zawodowych straży pożarnych (terenowych ZSP i zakładowych ZZSP) było jeszcze bardziej archaiczne. Wojewoda był przełożonym komendanta wojewódzkiego straży pożarnych, natomiast zawodowych straży pożarnych i zakładowych zawodowych straży pożarnych w strukturze urzędu nie było (ówczesnego urzędu wojewódzkiego). Były wówczas w strukturze obrony cywilnej województwa jako jednostki terenowe lub zakładowe. Jednym słowem ,pojedynczy dualizm” dawał możliwość wykazywania (z formalnego punktu widzenia), że straże pożarne nie istniały, choć na ich bazie budowane były jednostki przewidziane do militaryzacji, tak zwane kompanie zmilitaryzowane. Jak widać, na nieistniejącej strukturze można było sporządzić wiele statystyk $-\mathrm{w}$ rezultacie realizowano tak zwane bezpieczeństwo tabelkowe.

$\mathrm{Z}$ chwilą powstania samorządu terytorialnego z mocy ustawy z dnia 8 marca 1990 r. o samorządzie terytorialnym ${ }^{5}$ oraz gospodarki rynkowej (w tym przedsiębiorstw prywatnych) jednostki organizacyjne obrony cywilnej pozostały w mocy przepisów odnoszących się do coraz to węższej grupy adresatów niezreformowanej jeszcze administracji rządowej oraz w „przyzwyczajeniach” pracowników minionej epoki. Nie było jeszcze powiatów ani „dużych” (nowych) województw. Dopiero uchwalenie przez Sejm X kadencji ustaw o ochronie przeciwpożarowej i o Państwowej Straży Pożarnej spowodowało zapoczątkowanie przemian systemowych w bezpieczeństwie wewnętrznym, zarządzaniu kryzysowym, ratownictwie itp.

${ }^{4}$ Protokoły dodatkowe do Konwencji genewskich z 12 sierpnia 1949 r., dotyczący ochrony ofiar międzynarodowych konfliktów zbrojnych (Protokół I) oraz dotyczący ochrony ofiar nie międzynarodowych konfliktów zbrojnych (Protokół II), sporządzone w Genewie dnia 8 czerwca 1977 r., Dz.U. z 1992 r. Nr 41, poz. 175 i 176.

5 Obecnie ustawa o samorządzie gminnym, tekst jedn. z 2001 r. Dz.U. Nr 142, poz. 1591 ze zm. 
Nowa Konstytucja RP z dnia 2 kwietnia 1997 r. odnosiła się do zapewnienia przez państwo między innymi wolności, praw człowieka i obywatela oraz bezpieczeństwa obywateli. Natomiast Strategia Bezpieczeństwa Narodowego (od 2003 r.) oprócz bezpieczeństwa obywateli uwzględniała również ochronę majątku narodowego oraz granic Rzeczypospolitej Polskiej. A zatem, odwołując się do stwierdzenia byłego prezesa Trybunału Konstytucyjnego prof. Andrzeja Zolla, udzielonego $\mathrm{w}$ jednym $\mathrm{z}$ wywiadów, bezpieczeństwo winno być funkcją ograniczenia praw i wolności człowieka i obywatela. Przedstawione wyżej informacje ukazują tu tylko część zapoczątkowanych przemian oraz wskazują na powstanie pierwszego w dziejach naszego państwa cywilnego systemu reagowania na zagrożenia.

\section{KRAJOWY SYSTEM RATOWNICZO-GAŚNICZY}

Sejm X kadencji ustawami z dnia 24 sierpnia 1991 r. o ochronie przeciwpożarowej ${ }^{6}$ i o Państwowej Straży Pożarnej umożliwił utworzenie krajowego systemu ratowniczo-gaśniczego [KSRG] będącego integralną częścią organizacji bezpieczeństwa wewnętrznego państwa. Powstanie tych aktów prawnych możliwe było dzięki pracownikom naukowym Uniwersytetu Wrocławskiego (między innymi prof. Klimowicz, prof. Gromski, prof. Kocowski, dr Cenin, mgr Lamparski), strażakom zrzeszonym w strukturach związkowych NSZZ „Solidarność”, posłom na Sejm X kadencji (między innymi posłowie Geremek, Kosmalski, Michalak, Dynowska, Starownik, Zimnicki i inni).

Udział pracowników naukowych Uniwersytetu Wrocławskiego jest bezsporny, gdyż redagowanie normy prawnej nie było mocną stroną ówczesnych środowisk strażackich. Początkiem usytuowania KSRG w strukturze administracji rządowej państwa było utworzenie (po raz pierwszy w Polsce) formacji o jednolitej strukturze, posiadającej jednoznaczne narzędzia prawne oraz niezbędne siły i środki ${ }^{7}$.

Udział strażaków zrzeszonych w NSZZ „Solidarność” polegał na przyjęciu propozycji i koncepcji nowych rozwiązań prawnych zaproponowanych przez Dolnośląski Zespół Redakcyjny, skupiający wymienionych pracowników naukowych UWr oraz nieliczną grupę zawodowych strażaków z terenu Dolnego Śląska. Cytuję słowa dr. inż. M. Cenina: „związkowcy po raz pierwszy w kraju poparli utworzenie pracodawcy". Sekcja Krajowa oraz struktury wojewódzkie Związku wzięły na siebie zadanie propagowania nowych rozwiązań wśród „dołów strażackich” oraz parlamentarzystów — ze skutkiem bardzo pozytywnym ${ }^{8}$. Podczas prac legi-

6 Tekst jedn. Dz.U. z 2016 r., poz. 191.

7 Uzasadnienie do projektu ustawy o Państwowej Straży Pożarnej z 1990 r. przygotowane przez prof. Gromskiego.

${ }^{8}$ Podczas głosowania nad projektami ustaw — ustawa o ochronie przeciwpożarowej nie miała żadnego głosu przeciwnego - „przeszła” jednogłośnie. 
slacyjnych parlamentarzyści wykazywali duże zdziwienie istniejącym (raczej jego brakiem) stanem prawnym (z okresu PRL) oraz propozycjami przygotowanymi przez Dolnośląski Zespół Redakcyjny. Można ten proces opisać słowami ówczesnego Marszałka Senatu prof. Andrzeja Stelmachowskiego: ,punkt widzenia autorów ustaw bardziej pasuje do przepisów międzynarodowych jak do siermiężnej rzeczywistości prawnej w Polsce”.

Krajowy system ratowniczo-gaśniczy stanowi integralną część systemu bezpieczeństwa wewnętrznego państwa, obejmuje - w celu ratowania życia, zdrowia, mienia lub środowiska - prognozowanie, rozpoznawanie i zwalczanie pożarów, klęsk żywiołowych lub innych miejscowych zagrożeń. System ten skupia jednostki ochrony przeciwpożarowej, inne służby, inspekcje, straże, instytucje oraz podmioty, które dobrowolnie w drodze umowy cywilnoprawnej zgodziły się współdziałać w akcjach ratowniczych. Cele ochrony życia, zdrowia, mienia lub środowiska realizuje przez: walkę z pożarami lub innymi klęskami żywiołowymi, ratownictwo techniczne, ratownictwo chemiczne, ratownictwo ekologiczne, ratownictwo medyczne, współpracę z jednostkami systemu Państwowego Ratownictwa Medycznego, o których mowa w ustawie o Państwowym Ratownictwie Medycznym oraz ustawie o systemie powiadamiania ratunkowego.

Organizacja KSRG w Polsce zrealizowana jest na trzech poziomach: powiatowym, wojewódzkim i krajowym.

$\mathrm{Na}$ poziomie powiatowym system tworzą następujące podmioty systemu: komenda powiatowa (miejska) Państwowej Straży Pożarnej, jednostki ochrony przeciwpożarowej mające siedzibę na obszarze powiatu włączone do systemu, powiatowy zespół do zarządzania kryzysowego, włączone do systemu inne służby, inspekcje, straże i instytucje, o których mowa w definicji KSRG — ustawa o ochronie przeciwpożarowej - specjaliści w sprawach ratownictwa i inne podmioty, włączone do systemu w drodze umowy cywilnoprawnej.

Na poziomie wojewódzkim system tworzą następujące podmioty systemu: komenda wojewódzka Państwowej Straży Pożarnej, wydzielone siły i środki z poziomów powiatowych stanowiące wojewódzki odwód operacyjny, ośrodki szkolenia Państwowej Straży Pożarnej, wojewódzki zespół do spraw ochrony przeciwpożarowej i ratownictwa, krajowa baza sprzętu specjalistycznego Państwowej Straży Pożarnej, podmioty, włączone do systemu na poziomie wojewódzkim.

Na poziomie krajowym system tworzą następujące podmioty systemu: Komenda Główna Państwowej Straży Pożarnej, wydzielone siły i środki z wojewódzkich odwodów operacyjnych stanowiące centralny odwód operacyjny, szkoły Państwowej Straży Pożarnej, krajowe bazy sprzętu specjalistycznego Państwowej Straży Pożarnej, jednostki badawczo-rozwojowe ochrony przeciwpożarowej, podmioty włączone do systemu na poziomie krajowym. 


\section{PLANY RATOWNICZE POWIATU I WOJEWÓDZTWA}

Po kolejnej nowelizacji ustawy z dnia 26 kwietnia 2007 r. o zarządzaniu kryzysowym ${ }^{9}$ zobowiązano właściwe organy administracji publicznej do zapewnienia spójności między planami zarządzania kryzysowego a innymi planami sporządzanymi w tym zakresie na podstawie odrębnych przepisów. Zależność ta jest bardzo istotna, zważywszy, że plan ratowniczy powiatu zatwierdza starosta lub prezydent miasta na prawach powiatu. Natomiast ten starosta lub prezydent sporządza plan zarządzania kryzysowego powiatu, który z kolei zatwierdza wojewoda.

Plany operacyjne czy plany ratownicze były w ciągłym użytkowaniu jednostek organizacyjnych ochrony przeciwpożarowej (z okresu PRL) oraz jednostek organizacyjnych Państwowej Straży Pożarnej. Komendanci powiatowy (miejski) i wojewódzki Państwowej Straży Pożarnej opracowują plany ratownicze obszarów powiatu i województwa, których opracowanie poprzedza się:

- analizą zagrożeń występujących na danym obszarze, przy uwzględnieniu gęstości zaludnienia, warunków geograficzno-topograficznych, stanu infrastruktury oraz zagrożeń z obszarów sąsiadujących, w tym terenów objętych prawem górniczym, poligonów, wód przybrzeżnych oraz terenów państw ościennych,

- analizą zabezpieczenia operacyjnego podległego obszaru, określającą siły i środki niezbędne do ratowania życia, zdrowia, mienia i środowiska oraz ograniczenia, likwidacji lub usuwania potencjalnych zagrożeń, przy uwzględnieniu sił i środków własnych systemu oraz współdziałających z systemem na poszczególnych poziomach jego funkcjonowania.

\section{KONSTYTUCJA RP A BEZPIECZEŃSTWO WEWNĘTRZNE}

W art. 5 Konstytucji RP czytamy, że Rzeczpospolita Polska strzeże niepodległości i nienaruszalności swojego terytorium, zapewnia wolności i prawa człowieka i obywatela oraz bezpi eczeńst wo obywateli, strzeże dziedzictwa narodowego oraz zapewnia ochronę środowiska, kierując się zasadą zrównoważonego rozwoju. Natomiast w art. 146 ust. 4 pkt 7 wprowadzono termin „bezpieczeństwo wewnętrzne", którego zapewnienie, oprócz porządku publicznego, należy do Rady Ministrów.

W niniejszej pracy szczegółowo skupiono się na „bezpieczeństwie wewnętrznym” w odniesieniu do „bezpieczeństwa obywateli”, ponieważ krajowy system ratowniczo-gaśniczy stanowi jego (organizacyjnie) integralną część (art. 2 pkt 4 ustawy o ochronie przeciwpożarowej). System w celu ratowania życia, zdrowia, mienia lub środowiska obejmuje prognozowanie, rozpoznawanie i zwalczanie po-

\footnotetext{
${ }^{9}$ Dz.U. z 2013 r., poz. 1166 ze zm.
} 
żarów, klęsk żywiołowych lub innych miejscowych zagrożeń. Pojawiają się nowe terminy, które są zdefiniowane ustawowo.

W ustawie $\mathrm{z}$ dnia 18 kwietnia 2002 r. o stanie klęski żywiołowej ${ }^{10}$, jednej z trzech ustaw o stanach nadzwyczajnych, zdefiniowano klęskę żywiołową jako katastrofę naturalną lub awarię techniczną, której skutki zagrażają życiu lub zdrowiu dużej liczby osób, mieniu w wielkich rozmiarach albo środowisku na znacznych obszarach, a pomoc i ochrona mogą być skutecznie podjęte tylko przy zastosowaniu nadzwyczajnych środków, we współdziałaniu różnych organów i instytucji oraz specjalistycznych służb i formacji działających pod jednolitym kierownictwem. Katastrofą naturalną jest zdarzenie związane z działaniem sił natury, w szczególności wyładowania atmosferyczne, wstrząsy sejsmiczne, silne wiatry, intensywne opady atmosferyczne, długotrwałe występowanie ekstremalnych temperatur, osuwiska ziemi, pożary, susze, powodzie, zjawiska lodowe na rzekach i morzu oraz jeziorach i zbiornikach wodnych, masowe występowanie szkodników, chorób roślin lub zwierząt albo chorób zakaźnych ludzi, jak również działanie innego żywiołu.

Natomiast awaria techniczna to gwałtowne, nieprzewidziane uszkodzenie lub zniszczenie obiektu budowlanego, urządzenia technicznego lub systemu urządzeń technicznych, powodujące przerwę w ich używaniu lub utratę ich właściwości. Katastrofą naturalną lub awarią techniczną może być zdarzenie wywołane działaniem terrorystycznym.

Ustawa o ochronie przeciwpożarowej wprowadza termin ,inne miejscowe zagrożenie" rozumiane jako zdarzenie wynikające z rozwoju cywilizacyjnego i naturalnych praw przyrody, niebędące pożarem ani klęską żywiołową, stanowiące zagrożenie dla życia, zdrowia, mienia lub środowiska, któremu zapobieżenie lub usunięcie jego skutków nie wymaga zastosowania nadzwyczajnych środków.

\section{DZIAŁY ADMINISTRACJI RZĄDOWEJ}

Zgodnie z przepisami ustawy z dnia 4 września 1997 r. o działach administracji rządowej ${ }^{11}$ ochrona przeciwpożarowa jest elementem spraw wewnętrznych, które obejmują ochronę bezpieczeństwa i porządku publicznego, zarządzania kryzysowego, obrony cywilnej, ochrony przeciwpożarowej, przeciwdziałania skutkom klęsk żywiołowych i innych podobnych zdarzeń zagrażających bezpieczeństwu powszechnemu.

Za prowadzenie odpowiedniego działu administracji rządowej odpowiada właściwy minister kierujący tym działem, który może w drodze rozporządzenia

10 Tekst jedn. Dz.U. z 2014 r., poz. 333 ze zm.

11 Tekst jedn. Dz.U. z 2016 r., poz. 543. 
upoważnić do wykonywania zadania organ lub jednostkę organizacyjną podległą ministrowi, organ samorządu zawodowego, organizację gospodarczą lub organ rejestrowy.

Organom i jednostkom organizacyjnym samorządu terytorialnego zadania z zakresu administracji rządowej są zlecane w drodze ustawy lub porozumienia. Określona część zadań to zadania własne, do których należy ochrona przeciwpożarowa. Ochrona ta odnosi się również (art. 3) do osób fizycznych, osób prawnych, organizacji lub instytucji korzystających ze środowiska, budynku, obiektu budowlanego lub terenu. Odrębny artykuł odnosi się do właścicieli budynków, obiektów budowlanych lub terenów, którzy obowiązani są do:

- przestrzegania przeciwpożarowych wymagań techniczno-budowlanych, instalacyjnych i technologicznych;

- wyposażenia budynku, obiektu budowlanego lub terenu w wymagane urządzenia przeciwpożarowe i gaśnice;

- zapewnienia konserwacji oraz naprawy urządzeń przeciwpożarowych i gaśnic w sposób gwarantujący ich sprawne i niezawodne funkcjonowanie;

— zapewnienia osobom przebywającym w budynku, obiekcie budowlanym lub na jego terenie bezpieczeństwa i możliwości ewakuacji;

- przygotowania budynku, obiektu budowlanego lub terenu do prowadzenia akcji ratowniczej;

— zapoznania pracowników z przepisami przeciwpożarowymi;

- ustalenia sposobów postępowania na wypadek powstania pożaru, klęski żywiołowej lub innego miejscowego zagrożenia.

Należy zwrócić szczególną uwagę na fakt, że zapewnienie osobom przebywającym w budynku, obiekcie budowlanym lub w terenie bezpieczeństwa i możliwości ewakuacji jest obowiązkiem zarówno właściciela, jakim może być osoba fizyczna, organizacja czy instytucja, jak i organu administracji publicznej. Obowiązkiem tym jest również przygotowanie terenu do prowadzenia akcji ratowniczej organizowanej i prowadzonej przez organ podstawowy Państwowej Straży Pożarnej. Jest to szczególny obowiązek, ponieważ uprawnienia komendanta powiatowego czy miejskiego sięgają (ingerują) daleko w prawa wspomnianego właściciela, jak również osoby fizycznej. Komendant ma prawo żądania pomocy oraz „odstąpienia od zasad powszechnie uznanych za bezpieczne”. Należy również uwzględnić ustalenie sposobów postępowania na wypadek powstania pożaru, klęski żywiołowej lub innego miejscowego zagrożenia. Sposoby te są bardzo istotne dla użytkowników budynków, obiektów budowlanych lub terenów. Szczególnie w obiektach użyteczności publicznej czy zakładach pracy o dużym zagrożeniu dla życia zdrowia lub środowiska (szpitale, zakłady chemiczne, magazyny gazów itp.).

Odpowiedzialność za realizację obowiązków z zakresu ochrony przeciwpożarowej, stosownie do obowiązków i zadań powierzonych, przejmuje w całości lub w części ich zarządca lub użytkownik na podstawie zawartej umowy cywilnoprawnej ustanawiającej zarząd lub użytkowanie. W przypadku gdy umowa taka 
nie została zawarta, odpowiedzialność za realizację obowiązków z zakresu ochrony przeciwpożarowej spoczywa na faktycznie władającym budynkiem, obiektem budowlanym lub terenem. Należy zatem zauważyć, że odpowiedzialność ta obowiązuje od chwili rozpoczęcia użytkowania obiektu, budynku lub terenu. Innym przykładem odpowiedzialności jest art. 9 ustawy o ochronie przeciwpożarowej stanowiący o obowiązku każdego, kto zauważy pożar, klęskę żywiołową lub inne miejscowe zagrożenie, do powiadomienia osób znajdujących się w strefie zagrożenia oraz jednostkę ochrony przeciwpożarowej bądź policję lub wójta albo sołtysa. Innymi słowy, to każdy z obywateli, widząc zagrożenie, powinien bezwzględnie na nie reagować pod groźbą odpowiedzialności karnej za brak reakcji.

W ochronie przeciwpożarowej szczególną rolę odgrywa wojewoda jako wykonawca zadań i kompetencji Państwowej Straży Pożarnej na obszarze województwa. Wojewoda zadania te wykonuje przy pomocy komendanta wojewódzkiego Państwowej Straży Pożarnej. Oprócz Komendanta Głównego Państwowej Straży Pożarnej i starosty (odpowiednio na obszarze województwa, kraju lub powiatu) określa zadania krajowego systemu ratowniczo-gaśniczego, koordynuje jego funkcjonowanie i kontroluje wykonywanie wynikających z niego zadan, a w sytuacjach nadzwyczajnych zagrożeń życia, zdrowia lub środowiska kieruje tym systemem.

Wojewoda i starosta wykonują swoje zadania przy pomocy odpowiednio wojewódzkiego i powiatowego zespołu zarządzania kryzysowego, działających na podstawie ustawy z dnia 26 kwietnia 2007 r. o zarządzaniu kryzysowym ${ }^{12}$. Widzimy tu powiązanie ochrony przeciwpożarowej z zarządzaniem kryzysowym. Dawne zespoły ds. ochrony przeciwpożarowej i ratownictwa przekształciły się w zespoły reagowania, a następnie zarządzania kryzysowego. Wojewoda określa również zakres koordynowania przez wójta (burmistrza, prezydenta miasta) funkcjonowania krajowego systemu ratowniczo-gaśniczego na obszarze gminy. Zadanie to może być wykonywane przy pomocy komendanta gminnego ochrony przeciwpożarowej, jeżeli komendant taki został zatrudniony przez wójta (burmistrza, prezydenta miasta), albo przy pomocy komendanta gminnego związku ochotniczych straży pożarnych. W tym zakresie uprawnienia wojewody schodzą aż do gminy, dla której ochrona przeciwpożarowa (jak już wspomniałem) jest zadaniem własnym.

Należy zauważyć, że wojewoda jest w tym zakresie organem kierującym, koordynującym, nadzorującym i kontrolującym — mimo że nie ma własnego aparatu wykonawczego. Korzysta z jednostek organizacyjnych podległych innym organom administracji publicznej lub inaczej — korzysta z uprawnień zwierzchnika administracji zespolonej. Uprawnienia te przejawiają się w wydawaniu zarządzeń lub zawieraniu porozumień. Od 2003 r. obowiązują (nowelizowane) zarządze-

12 Dz.U. Nr 89, poz. 590, ze zm. 
nia odnoszące się do krajowego systemu ratowniczo-gaśniczego ${ }^{13}$. Innym przykładem są porozumienia wojewody zawierane między innymi z komendantami wojewódzkimi Policji i Państwowej Straży Pożarnej, marszałkiem województwa dolnośląskiego czy prezydentem Wrocławia.

\section{ZADANIA WOJEWODY}

Zgodnie z ustawą z dnia 23 stycznia 2009 r. o wojewodzie i administracji rządowej w województwie ${ }^{14}$ administrację rządową wykonują: wojewoda; organy rządowej administracji zespolonej w województwie, w tym kierownicy zespolonych służb, inspekcji i straży; organy niezespolonej administracji rządowej; jednostki samorządu terytorialnego i ich związki - jeżeli wykonywanie przez nie zadań administracji rządowej wynika $\mathrm{z}$ odrębnych ustaw lub zawartego porozumienia; starosta - jeżeli wykonywanie przez niego zadań administracji rządowej wynika z odrębnych ustaw; inne podmioty — jeżeli wykonywanie przez nie zadań administracji rządowej wynika z odrębnych ustaw.

Wojewoda jest:

— przedstawicielem Rady Ministrów w województwie;

— zwierzchnikiem rządowej administracji zespolonej w województwie;

— organem rządowej administracji zespolonej w województwie;

— organem nadzoru nad działalnością jednostek samorządu terytorialnego i ich związków pod względem legalności;

— organem administracji rządowej w województwie, do którego właściwości należą wszystkie sprawy z zakresu administracji rządowej w województwie niezastrzeżone w odrębnych ustawach do właściwości innych organów tej administracji;

- reprezentantem skarbu państwa w zakresie i na zasadach określonych w odrębnych ustawach;

— organem wyższego stopnia w rozumieniu kodeksu postępowania administracyjnego.

W 2009 r. podjęto próbę połączenia krajowego systemu ratowniczo-gaśniczego i Państwowego Ratownictwa Medycznego ${ }^{15} \mathrm{z}$ utworzeniem „systemu powiadamiania ratunkowego" do realizacji następujących zadań:

${ }^{13}$ Zob. zarządzenie nr 50 Wojewody Dolnośląskiego z dnia 25 lutego 2008 r. w sprawie określenia zakresu koordynowania przez wójta (burmistrza lub prezydenta miasta) funkcjonowania krajowego systemu ratowniczo-gaśniczego na obszarze gminy, oraz zarządzenie $\mathrm{nr} 51$ Wojewody Dolnośląskiego z dnia 25 lutego 2008 r. w sprawie określenia zadań krajowego systemu ratowniczo-gaśniczego na terenie województwa dolnośląskiego.

14 Tekst jedn. Dz.U. z 2015 r., poz. 525.

15 Ustawa z dnia 8 września 2006 r. o Państwowym Ratownictwie Medycznym, tekst jedn. Dz.U. z 2013 r., poz. 575. 
— bieżącej analizy zasobów ratowniczych,

— przyjmowania zgłoszeń alarmowych oraz obsługi numeru alarmowego 112,

— podejmowania działań z określonymi procedurami, w szczególności:

a) dysponowania sił ratowniczych i zespołów ratownictwa medycznego,

b) koordynowania oraz monitorowania działań ratowniczych i medycznych, a także czynności ratunkowych,

c) powiadamiania o zdarzeniu szpitalnych oddziałów ratunkowych lub - jeżeli wymaga tego sytuacja na miejscu zdarzenia — jednostek organizacyjnych szpitali wyspecjalizowanych w zakresie udzielania świadczeń zdrowotnych niezbędnych dla ratownictwa medycznego,

d) inicjowania procedur reagowania kryzysowego.

Próba utworzenia „systemu powiadamiania ratunkowego” okazała się niemożliwa do zrealizowania ze względu na niejednoznaczne uwarunkowania prawne w organizacji systemu Państwowego Ratownictwa Medycznego w Polsce. Dopiero uchwalenie ustawy z dnia 14 listopada 2013 r. o systemie powiadamiania ratunkowego w głównej mierze przyczyniło się ${ }^{16}$ do właściwej jego organizacji.

Podmioty systemu Państwowego Ratownictwa Medycznego podlegają niezależnym od wojewody organom samorządu województwa lub podmiotom prywatnym. Umowy na wykonanie świadczeń przez jednostki systemu zawiera właściwy terytorialnie dyrektor Narodowego Funduszu Zdrowia. Można zauważyć, że w Polsce istnieją „dwa” ratownictwa medyczne. Jedno, które wynika z ustawy o Państwowym Ratownictwie Medycznym, a drugie wynikające z ustawy o ochronie przeciwpożarowej (art. 14 ust. 1 pkt 5). Co prawda, ratownictwa te mają z sobą współdziałać, jednak nie określono, na jakich zasadach i kto te zasady ma określić, a następnie egzekwować lub kontrolować.

\section{PAŃSTWOWA STRAŻ POŻARNA}

Państwowa Straż Pożarna jest formacją zawodową, umundurowaną i wyposażoną w specjalistyczny sprzęt, przeznaczoną do walki z pożarami, klęskami żywiołowymi i innymi miejscowymi zagrożeniami. Do jej podstawowych zadań należy:

— rozpoznawanie zagrożeń pożarowych i innych miejscowych zagrożeń;

— organizowanie i prowadzenie akcji ratowniczych w czasie pożarów, klęsk żywiołowych lub likwidacji miejscowych zagrożeń;

- wykonywanie pomocniczych specjalistycznych czynności ratowniczych w czasie klęsk żywiołowych lub likwidacji miejscowych zagrożeń przez inne służby ratownicze;

— kształcenie kadr na potrzeby Państwowej Straży Pożarnej i innych jednostek ochrony przeciwpożarowej oraz powszechnego systemu ochrony ludności;

16 Dz.U. z 2013 r., poz. 1635, ze zm. 
— nadzór nad przestrzeganiem przepisów przeciwpożarowych;

— prowadzenie prac naukowo-badawczych w zakresie ochrony przeciwpożarowej oraz ochrony ludności;

- współpraca z szefem Krajowego Centrum Informacji Kryminalnych w zakresie niezbędnym do realizacji jego zadań ustawowych;

— współdziałanie ze strażami pożarnymi i służbami ratowniczymi innych państw oraz ich organizacjami międzynarodowymi na podstawie wiążących Rzeczpospolitą Polską umów międzynarodowych oraz odrębnych przepisów;

— realizacja innych zadań wynikających z wiążących Rzeczpospolitą Polską umów międzynarodowych na zasadach i w zakresie w nich określonych.

Jednostki organizacyjne Państwowej Straży Pożarnej: Komenda Główna; komenda wojewódzka; komenda powiatowa (miejska); Szkoła Główna Służby Pożarniczej oraz pozostałe szkoły; jednostki badawczo-rozwojowe; Centralne Muzeum Pożarnictwa.

W skład komendy wojewódzkiej Państwowej Straży Pożarnej mogą wchodzić ośrodki szkolenia; w skład komendy powiatowej (miejskiej) Państwowej Straży Pożarnej wchodzą jednostki ratowniczo-gaśnicze. Zmieniając zaproponowane przez autorów ustaw zapisy ustawowe, że jednostki organizacyjne Państwowej Straży Pożarnej nie są odrębnymi jednostkami, spowodowano, że pożary mogą gasić urzędy, jakimi są komendy powiatowe czy wojewódzkie oraz Muzeum Pożarnictwa. Zadaniem Państwowej Straży Pożarnej nie jest wyłącznie prowadzenie działań ratowniczych wynikających z ustawy o ochronie przeciwpożarowej, lecz wiele innych zadań związanych z organizowaniem akcji ratowniczych, prowadzeniem czynności kontrolno-rozpoznawczych, szkoleniami kadr itp.

Akcja ratownicza to działania ratownicze organizowane i kierowane przez Państwową Straż Pożarną, co nie jest równoznaczne z prowadzeniem działań ratowniczych. Strażacy biorący udział w akcji ratowniczej, w zakresie niezbędnym do prowadzenia akcji, mają prawo do korzystania z dróg, gruntów i zbiorników wodnych państwowych, komunalnych i prywatnych oraz komunalnych i prywatnych ujęć wodnych i środków gaśniczych.

W okolicznościach uzasadnionych stanem wyższej konieczności strażak kierujący akcją ratowniczą ma prawo zarządzenia: ewakuacji ludzi i mienia z terenu objętego akcją ratowniczą; koniecznych prac wyburzeniowych i rozbiórkowych; wstrzymania komunikacji w ruchu lądowym; udostępnienia pojazdów, środków i przedmiotów niezbędnych do akcji ratowniczej; zakazu przebywania osobom postronnym $w$ rejonie akcji ratowniczej.

Ponadto $\mathrm{w}$ takich okolicznościach kierujący akcją ma prawo żądania niezbędnej pomocy od instytucji państwowych, jednostek gospodarczych, organizacji społecznych i obywateli, a także odstąpienia od zasad działania uznanych powszechnie za bezpieczne.

Do odstąpienia od zasad działania uznanych powszechnie za bezpieczne, $\mathrm{z}$ zachowaniem wszelkich dostępnych $\mathrm{w}$ danych warunkach zabezpieczeń, może 
dojść, jeżeli w ocenie kierującego działaniem ratowniczym dokonanej w miejscu i czasie zdarzenia istnieje prawdopodobieństwo uratowania życia ludzkiego, w szczególności gdy z powodu braku specjalistycznego sprzętu zachodzi konieczność zastosowania sprzętu zastępczego, fizyczne możliwości ratownika mogą zastąpić brak możliwości użycia właściwego sprzętu, jest możliwe wykonanie określonej czynności przez osobę zgłaszającą się dobrowolnie.

Zarządzenia kierującego działaniem ratowniczym są decyzjami, którym może być nadany rygor natychmiastowej wykonalności, w trybie przepisów kodeksu postępowania administracyjnego.

\section{PODSUMOWANIE}

Analizując aktualny stan prawny, można wywnioskować, że najlepiej opisaną dziedziną $\mathrm{w}$ administracji rządowej (sprawy wewnętrzne - w rozumieniu ustawy o działach administracji rządowej) jest ochrona przeciwpożarowa, operująca normami kodeksu cywilnego. Przepisy ochrony przeciwpożarowej wskazują konkretnego adresata, którymi są osoby fizyczne, przedsiębiorcy, instytucje, właściciel lub użytkownicy. Umożliwiają również tworzenie jednostek ochrony przeciwpożarowej, mogących prowadzić samodzielnie działania ratowniczo-gaśnicze, definiuje podstawy do współdziałania organów i jednostek organizacyjnych administracji rządowej i samorządowej. Ochrona przeciwpożarowa ma narzędzia do realizacji zadań techniczno-prawnych mających na celu tworzenie rozwiązań systemowych oraz podejmowania działań profilaktycznych i przygotowawczych przez budowanie i wyposażanie baz sprzętu do zwalczania skutków klęsk żywiołowych lub innych miejscowych zagrożeń. Zgodnie z opinią Ministerstwa Spraw Wewnętrznych i Administracji skierowaną do wojewodów w 2003 r. ochrona przeciwpożarowa przejęła część zadań obrony cywilnej oraz powszechnego obowiązku obrony. Świadczy o tym jednoznacznie przepis $\S 4$ pkt 5 rozporządzenia Rady Ministrów z dnia 6 września 1993 r. w sprawie świadczeń na rzecz obrony. $W$ rozumieniu przepisów niniejszego rozporządzenia jednostką organizacyjną wykonującą zadania na potrzeby obrony państwa jest też Państwowa Straż Pożarna. Rozporządzenie to zostało znowelizowane w 2002 i 2004 r., zachowując wspomniany stan prawny w kwestii udziału Państwowej Straży Pożarnej w obronności kraju. W publikacji wykazano potrzebę zwrócenia większej uwagi jednostek organizacyjnych administracji rządowej i samorządowej podczas realizacji zapisów ustawowych $\mathrm{w}$ ramach wykonywania administracji publicznej. 


\section{NATIONAL FIREFIGHTING AND RESCUE SYSTEM (NFRS) IN THE STATE INTERNAL SECURITY SYSTEM}

\section{Summary}

National Firefighting and Rescue System was formed on 1 January 1995 under the Act of 24 August 1991. The Act, which initiated a change in our state internal security system, changing its paramilitary character into civilian. Despite the laws of a bygone era of communism the creation of the State Fire Service as a separate formation within the Ministry of Internal Affairs allowed ,the exclusion" of organizational units of the fire brigade of the Civil Defence so-called ,rescue units group".

This formation was obliged to create the National Rescue and Fire Fighting, possessing the power switch to the system of other units of fire protection services, inspections, internships, institutions and entities that voluntarily on the basis of a civil contract agreed to cooperate in rescue operations.

This system gives permission to the Chief Commander in the State Fire Service, Provincial and District Heads to determine (respectively in the country, province or district) the tasks, coordinate operation and manage it in extreme situation.

The Provincial Governor and the District Head carry out their tasks with the appropriate provincial and district crisis management team, operating under the Act of 26 April 2007. Crisis Management (Dz.U. Journal of Laws No. 89, item. 590, as amended. Amendment 2).

The Village Head has the authority supervised by the mayor or city president, who coordinates the operation of the National Firefighting and Rescue System within the municipality to the extent determined by the Provincial Governor. In other words, the system enables the interaction of organizational units of government, local government, private entities and public benefit organizations.

The relevant Governors play a meaningful role in this system. They perform tasks and powers of the State Fire Service with the help of provincial commanders of the State Fire Service in the province. 